\title{
HPTLC-Densitometric Analysis of Eperisone Hydrochloride and Paracetamol in Their Combined Tablet Dosage Form
}

\author{
Nirav Uchadadiya, Falgun Mehta, and Pinak Sanchaniya \\ Department of Pharmaceutical Chemistry and Analysis, Indukaka Ipcowala College of Pharmacy, New Vallabh Vidyanagar, \\ Gujarat 388121, India \\ Correspondence should be addressed to Nirav Uchadadiya; nikup982@gmail.com
}

Received 28 February 2013; Accepted 16 April 2013

Academic Editor: Irene Panderi

Copyright (C) 2013 Nirav Uchadadiya et al. This is an open access article distributed under the Creative Commons Attribution License, which permits unrestricted use, distribution, and reproduction in any medium, provided the original work is properly cited.

\begin{abstract}
A simple, precise, accurate, and reliable HPTLC method has been developed and validated for the analysis of EPE-Eperisone hydrochloride and PCM-Paracetamol in their combined dosage form. Identification and analysis were performed on $100 \mathrm{~mm} \times$ $100 \mathrm{~mm}$ layer thickness $0.2 \mathrm{~mm}$, precoated silica gel $\mathrm{G}_{60}-\mathrm{F}_{254}$ aluminum sheet, prewashed with methanol, and dried in an oven at $50^{\circ} \mathrm{C}$ for 5 min. Toluene : methanol : ethyl acetate : glacial acetic acid $(4: 3.5: 2.5: 0.05)(\mathrm{v} / \mathrm{v} / \mathrm{v} / \mathrm{v})$ was used as mobile phase. Calibration plots were established showing the dependence of response (peak area) on the amount chromatographed. The validated calibration ranges were 200-700 ng/spot and 1300-4550 ng/spot for EPE and PCM with correlation coefficient $\left(R^{2}\right) 0.994$ and 0.996 , respectively. Average \% recovery was between $98.61-100.94 \%$ and $99.18-100.57 \%$ for EPE and PCM, respectively. The spots were scanned at $248 \mathrm{~nm}$ in a reflectance mode. The proposed method was validated as per ICH guidelines and successfully applied to the estimation of EPE and PCM in their combined tablet dosage form.
\end{abstract}

\section{Introduction}

EPE is chemically (2RS)-1-(4-ethylphenyl)-2-methyl-3-(1-piperidinyl)propan-1-one and hydrochloride (1:1) (Figure 1(a)) $[1,2]$. Eperisone $\mathrm{HCl}$ is a centrally acting muscle relaxant; it acts at the level of spinal cord by blocking sodium channels and calcium channels. Eperisone $\mathrm{HCl}$ exerts its spinal reflex inhibitory action predominantly via a presynaptic inhibition of the transmitter release from the primary afferent endings via a combined action on voltage-gated sodium and calcium channels. Eperisone $\mathrm{HCl}$ increases the blood supply to skeletal muscles; this action is noteworthy since a muscle contracture may compress the small blood vessels and induce an ischemia leading to release of pain stimulating compounds [3]. EPE is official in Japanese pharmacopoeia [1]. Chemically PCM is N-(4-hydroxyphenyl)acetamide (Figure 1(b)). Paracetamol is a weak inhibitor of PG-Prostaglandin synthesis of COX-1 and COX-2. Cyclooxygenase serves as a pain activator, is responsible for the biosynthesis of prostaglandins, is used for the relief of headaches, fever, pains, and is a major ingredient in numerous cold and flu remedies [4]. Paracetamol is official in Japanese Pharmacopoeia [1], British Pharmacopoeia [5], United States Pharmacopoeia [6], and Indian Pharmacopoeia [7].

The review of the literature revealed that analytical methods involving spectrophotometry [8], LC-ESI-MS [9], have been reported for EPE in single form and in combination with other drugs. Several analytical methods have been reported for PCM in single form and in combination with other drugs including spectrophotometry [10-14], HPLC [15-17], and HPTLC $[18,19]$.

To the best of our knowledge, there is no published HPTLC method for this combination. So, the present paper describes a simple, accurate, and precise method for simultaneous estimation of EPE and PCM in combined tablet dosage form by HPTLC method. The developed method was validated in accordance with ICH guidelines [20] and successfully employed for the assay of EPE and PCM in their combined dosage form. 


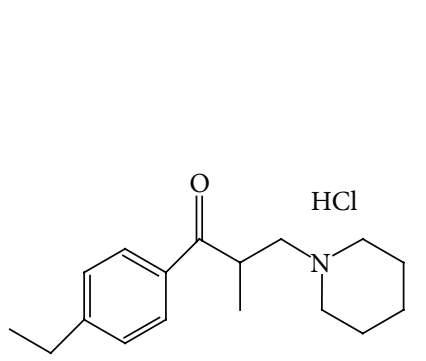

(a)<smiles>CC(=O)Nc1ccc(O)cc1</smiles>

(b)
Figure 1: Chemical structure of (a) EPE and (b) PCM.

\section{Materials and Methods}

2.1. Reagents and Chemicals. Analytically pure EPE and PCM were kindly provided by Macleods Pharmaceuticals Ltd., Mumbai, Maharashtra, India, and Elysium Pharmaceutical Ltd., Vadodara, Gujarat, India, respectively, as gratis samples. Analytical grade methanol was purchased from SRL limited, Mumbai, India. Tablet of EPE and PCM in combined dosage form, MYOSONE PLUS, with a $50 \mathrm{mg}$ EPE and $325 \mathrm{mg}$ PCM label claim, manufactured by Macleods Pharmaceuticals Ltd., was procured from local market.

2.2. Instrumentation and Conditions. Chromatography was performed on $100 \mathrm{~mm} \times 100 \mathrm{~mm}$ on precoated silica gel $\mathrm{G}_{60^{-}}$ $\mathrm{F}_{254}$ aluminum sheet (E. Merck, Mumbai, India). Before use the plates were washed with methanol then dried at room temperature. Samples were applied as $6 \mathrm{~mm}$ bands by means of a Camag Linomat V (Muttenz, Switzerland) sample applicator equipped with $100 \mu \mathrm{L}$ syringe; operated with settings of band length, $6 \mathrm{~mm}$; distance between bands, $5 \mathrm{~mm}$; distance from the plate edge, $10 \mathrm{~mm}$; and distance from the bottom of the plate, $10 \mathrm{~mm}$. The constant application rate was $15 \mathrm{~s} \mu \mathrm{L}^{-1}$, and a nitrogen aspirator was used. Ascending development of plate, migration distance $70 \mathrm{~mm}$ was performed at ambient temperature with Toluene: methanol:ethyl acetate: glacial acetic acid $(4: 3.5: 2.5: 0.05)(\mathrm{v} / \mathrm{v} / \mathrm{v} / \mathrm{v})$, as mobile phase in a $10 \mathrm{~cm} \times 10 \mathrm{~cm}$ Camag twin-trough chamber previously saturated for $15 \mathrm{~min}$. After development the plates were dried with hot-hair dryer and viewed in a CAMAG UV cabinet. Densitometric scanning at $272 \mathrm{~nm}$ was then performed with a Camag TLC Scanner 3 equipped with winCATs 3.2.1 software. The scanning rate was $20 \mathrm{~mm} \mathrm{~s}^{-1}$. The source of radiation used was the deuterium lamp.

\subsection{Calibration}

2.3.1. Eperisone Hydrochloride $(50 \mu \mathrm{g} / \mathrm{mL})$ and Paracetamol $(325 \mu \mathrm{g} / \mathrm{mL})$ Standard Stock Solution. Standard EPE $50 \mathrm{mg}$ and PCM $325 \mathrm{mg}$ were weighed and transferred to a $100 \mathrm{~mL}$ volumetric flask and dissolved in methanol. The flask was sonicated, and volume was made up to the mark with methanol to give a solution containing $500 \mu \mathrm{g} / \mathrm{mL}$ EPE and $3250 \mu \mathrm{g} / \mathrm{mL}$ PCM. One $\mathrm{mL}$ of this aliquot was added to $10 \mathrm{~mL}$ volumetric flask, and volume was made up to the mark with
TABLE 1: System suitability test parameters.

\begin{tabular}{lcc}
\hline $\begin{array}{l}\text { System suitability } \\
\text { parameter }\end{array}$ & EPE & PCM \\
\hline $\begin{array}{l}\text { Peak purity } \\
R_{f} \text { value }\end{array}$ & 0.994 & 0.996 \\
\hline
\end{tabular}

methanol to give a solution containing $50 \mu \mathrm{g} / \mathrm{mL}$ EPE and $325 \mu \mathrm{g} / \mathrm{mL}$ PCM.

2.3.2. Calibration Curve for EPE and PCM. Semiautomatic spotter was used containing a syringe having capacity of $100 \mu \mathrm{L}$. Mixed stock solution having concentration of $50 \mu \mathrm{g} / \mathrm{mL}$ of EPE and $325 \mu \mathrm{g} / \mathrm{mL}$ PCM was filled in the syringe, and under nitrogen stream, it was applied in the form of band of desired concentration range for each drug on a single plate having concentration of 200 to $700 \mathrm{ng}$ /spot for EPE and 1300 to $4550 \mathrm{ng} / \mathrm{spot}$ for PCM. Plate was developed using the above-mentioned conditions. Plots of peak area versus concentration for both drugs were obtained.

2.4. Analysis of Marketed Formulation. Twenty tablets were weighed accurately; average weight was found and finely powered. A quantity equivalent to $50 \mathrm{mg}$ EPE and $325 \mathrm{mg}$ PCM was accurately weighed and transferred to volumetric flask of $100 \mathrm{~mL}$ capacity. $80 \mathrm{~mL}$ of methanol was transferred to this volumetric flask and sonicated for $20 \mathrm{~min}$ to dissolve the drug. Resulting solution was filtered through Whatman filter paper $(0.45 \mu)$ into a $100 \mathrm{~mL}$ volumetric flask. The flask was shaken, and volume was made up to the mark with methanol to give a solution containing $500 \mu \mathrm{g} / \mathrm{mL}$ of EPE and $3250 \mu \mathrm{g} / \mathrm{mL}$ of PCM. One $\mathrm{mL}$ of this aliquot was added to $10 \mathrm{~mL}$ volumetric flask, and volume was made up to the mark with methanol to give a solution containing $50 \mu \mathrm{g} / \mathrm{mL}$ of EPE and $325 \mu \mathrm{g} / \mathrm{mL}$ of PCM. Now this prepared sample solution was applied on TLC plate, developed, dried in air, and photometrically analyzed as described above. From the peak area obtained in the chromatogram, the amounts of both of the drugs were calculated.

\subsection{Validation of the Method}

2.5.1. Linearity and Range of the HPTLC Method. Calibration graphs were constructed by plotting peak areas versus concentrations of EPE and PCM, and the regression equations were calculated. The calibration graphs were plotted over 6 different concentrations in the range of 200-700 ng/spot for EPE and 1300-4550 ng/spot for PCM by applying different volumes stock solution containing EPE and PCM $(50 \mu \mathrm{g} / \mathrm{mL}$ of EPE and $325 \mu \mathrm{g} / \mathrm{mL}$ PCM). The calibration graphs were developed by plotting peak area versus concentrations $(n=6)$ with the help of the winCATS software.

2.5.2. Accuracy (Recovery). Known amounts of standard solution of EPE (300, 400, and $500 \mathrm{ng} / \mathrm{spot})$ and PCM (2050, 2600, and $3250 \mathrm{ng} / \mathrm{spot}$ ) for the HPTLC method were added 
TABLE 2

\begin{tabular}{lcc}
\hline Concentration (ng/spot) & Area mean \pm S.D. $(n=6)$ & CV \\
\hline & Result of calibration readings for EPE by HPTLC method & 1.15 \\
300 & $1194.333 \pm 13.80821$ & 0.87 \\
400 & $1675.967 \pm 14.6988$ & 0.85 \\
500 & $2093.35 \pm 17.86894$ & 1.4 \\
600 & $2504.867 \pm 35.20316$ & 0.91 \\
700 & $3171.433 \pm 29.04952$ & 0.66 \\
\hline & $3645.45 \pm 23.91458$ & 0.92 \\
1300 & Result of calibration readings for PCM by HPTLC method & 1.06 \\
1950 & $9337.983 \pm 86.3672$ \\
3200 & $11511.37 \pm 122.5659$ & 0.63 \\
3900 & $13646.1 \pm 86.2213$ & 0.62 \\
4550 & $16556.83 \pm 104.0746$ & 0.71 \\
& $18071.97 \pm 129.3408$ & 0.53 \\
\hline
\end{tabular}

TABLE 3: Determination of accuracy.

\begin{tabular}{|c|c|c|c|c|c|c|}
\hline \multirow{2}{*}{ \% Level } & \multicolumn{2}{|c|}{ Amount added (ng/spot) } & \multicolumn{2}{|c|}{ Amount recovered (ng/spot) $(n=3)$} & \multicolumn{2}{|c|}{$\%$ Recovered \pm S.D } \\
\hline & EPE & PCM & EPE & PCM & $\mathrm{EPE}$ & PCM \\
\hline 50 & 300 & 2050 & 302.82 & 2057.17 & $100.94 \pm 0.89$ & $100.35 \pm 0.41$ \\
\hline 100 & 400 & 2600 & 394.44 & 2578.68 & $98.61 \pm 0.74$ & $99.18 \pm 0.50$ \\
\hline 150 & 500 & 3250 & 492.95 & 3268.52 & $98.59 \pm 0.57$ & $100.57 \pm 0.93$ \\
\hline
\end{tabular}

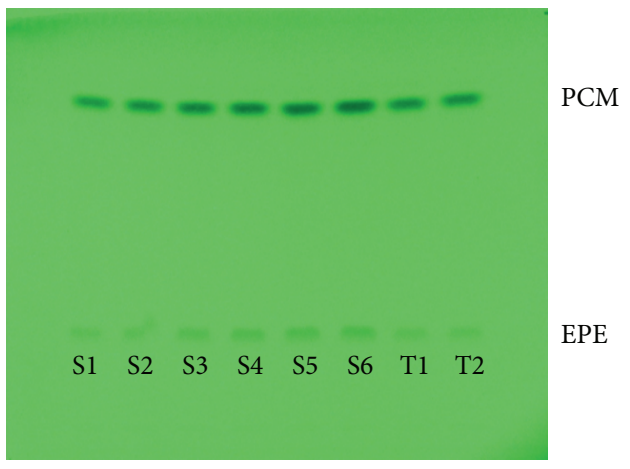

FIGURE 2: Photograph of developed HPTLC plate of EPE and PCM at $248 \mathrm{~nm}$.

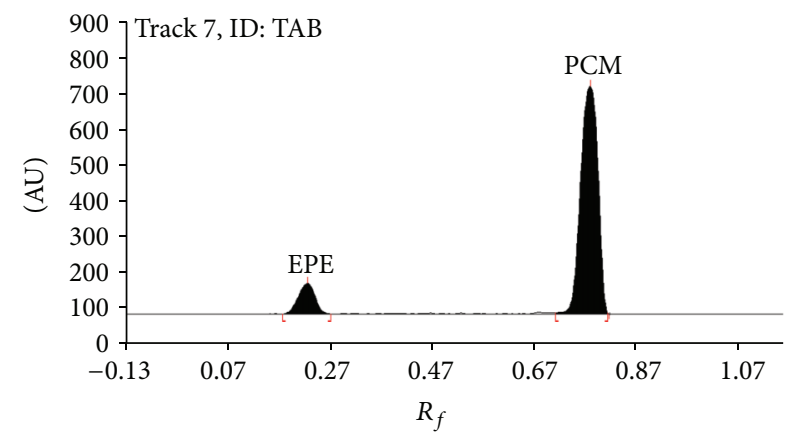

FIGURE 3: Densitogram of market formulation containing EPE and PCM $400 \mathrm{ng} / \mathrm{spot}$ and $2600 \mathrm{ng} / \mathrm{spot}$, respectively.

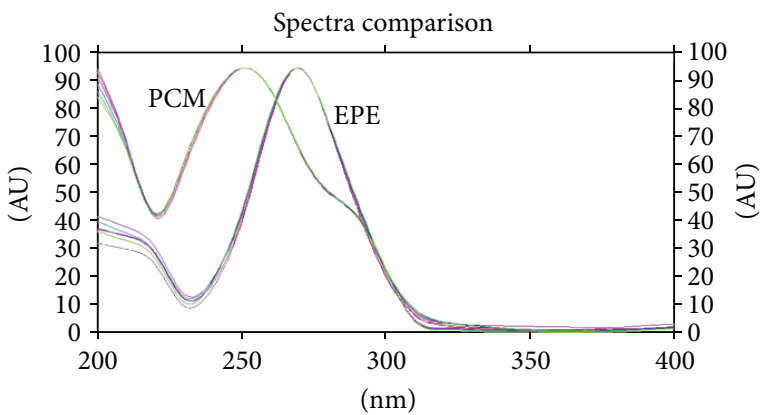

Figure 4: Overlain spectrums of EPE and PCM at $248 \mathrm{~nm}$ by HPTLC method.

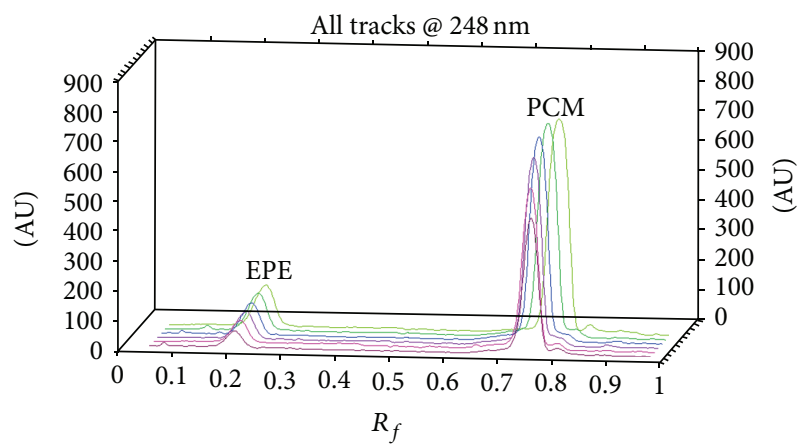

FIGURE 5: 3D overlain spectra of EPE and PCM by HPTLC method. 

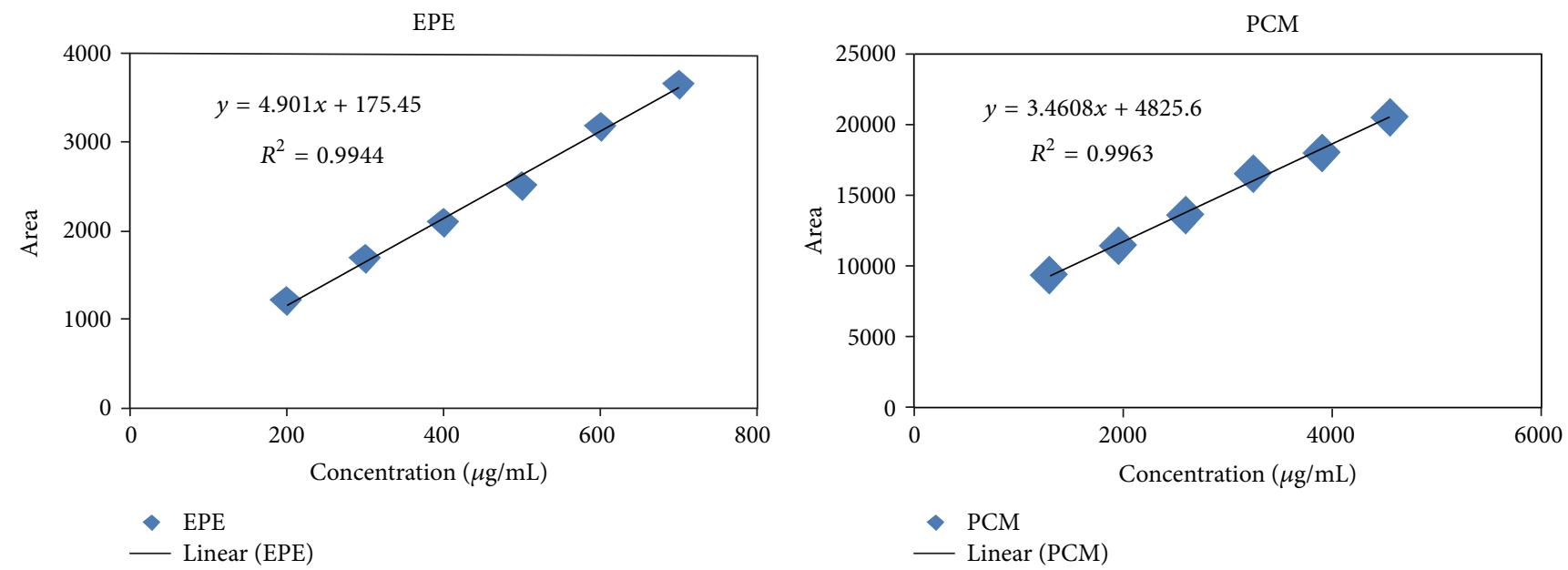

FIgURE 6: Calibration curve of EPE and PCM.

to prequantitated sample solutions of tablet dosage forms. The amounts of EPE and PCM were estimated by applying values of peak area to the regression equations of the calibration graph.

2.5.3. Precision. Precisions of the proposed HPTLC methods were determined by analyzing mixed standard solution of EPE and PCM at 3 different concentrations (300, 400, and $500 \mathrm{ng} / \mathrm{spot}$ for EPE and 1950, 2600, and $3250 \mathrm{ng} / \mathrm{spot}$ for PCM) 3 times in the same day and in 3 different days. The results are reported in terms of coefficient of variance $(\mathrm{CV})$.

2.5.4. Repeatability. Repeatability of method was assessed by applying the same sample solution 6 times on a plate with the automatic spotter using the same syringe and by taking 6 scans of the sample spot for both EPE and PCM (400 ng/spot of EPE and $2600 \mathrm{ng} / \mathrm{spot}$ of PCM) without changing the positions of the plate.

2.5.5. Specificity. The specificity of the method was ascertained by analyzing standard drug and sample. The band of EPE and PCM in sample was confirmed by comparing the $R_{f}$ and spectra of the band with that of standard. The peak purity of both drugs was assessed by comparing the spectra at 3 different levels, that is, peak start (S), peak apex (M), and peak end (E) position of the band.

2.5.6. Limit of Detection and Limit of Quantification. The limit of detection (LOD) and the limit of quantification (LOQ) of the drug were derived by using the following equations as per International Conference on Harmonization (ICH) guidelines which is based on the calibration curve:

$$
\begin{aligned}
& \mathrm{LOD}=3.3 \times \frac{\sigma}{S}, \\
& \mathrm{LOQ}=10 \times \frac{\sigma}{S},
\end{aligned}
$$

where $\sigma$ is the standard deviation of $y$-intercepts of regression lines and $S$ is slope of calibration curve.
2.5.7. Robustness. Sample solution was prepared and then analyzed with change in the typical analytical conditions like amount of mobile phase, proportion of mobile phase, saturation time, plate pretreatment, and stability of analytical solution.

\section{Results and Discussion}

3.1. Method Optimization. Several mobile phases were tried to accomplish good separation of EPE and PCM. Using the mobile phase Toluene : methanol : ethyl acetate : glacial acetic acid $(4: 3.5: 2.5: 0.05)(\mathrm{v} / \mathrm{v} / \mathrm{v} / \mathrm{v})$ and $10 \times 10 \mathrm{~cm} \mathrm{HPTLC} \mathrm{silica}$ gel 60 F254 aluminum-backed plates, good separation was attained with retention factor $\left(R_{f}\right)$ values of 0.26 for EPE and 0.79 for PCM. A wavelength of $248 \mathrm{~nm}$ was used for the quantification of the drugs. Figure 2 shows the detection of both of the drugs in their combined dosage form at $248 \mathrm{~nm}$ by HPTLC method. Resolution of the peaks with clear baseline separation was found. Figure 3 shows the densitogram of mixture which has a clear baseline. Figure 4 showed a good linearity when overlapped and scanned between $200 \mathrm{~nm}$ to $400 \mathrm{~nm}$. Figure 5 shows a 3D overlapped spectrum of both drugs which has good linearity. The system suitability test parameters for the developed method are shown in Table 1.

\subsection{Validation of the Proposed Methods}

3.2.1. Linearity. Figure 6 shows that linear correlation was obtained between peak areas and concentrations of EPE and PCM in the range of 200-700 ng/spot for EPE with $R^{2}=$ 0.994 and 1300-4550 ng/spot for PCM with $R^{2}=0.996$, respectively, and data are shown in Table 2.

3.2.2. Accuracy. The recovery experiments were performed by the standard addition method. The HPTLC method was found to be accurate with \% recovery of 98.61-100.94\% for EPE and 99.18-100.57\% for PCM, respectively, (Table 3). The high values indicate that the method is accurate. 
TABLE 4: Summary of validation parameters of HPTLC.

\begin{tabular}{lcc}
\hline Parameters & EPE & PCM \\
\hline Recovery $\%$ & $99.59-100.94$ & $99.18-100.57$ \\
Repeatability $(\mathrm{CV}, n=6)$ & 0.69 & 0.35 \\
Precision $(\mathrm{CV})$ & & $0.35-0.59$ \\
$\quad$ Intraday $(n=3)$ & $0.69-0.76$ & $0.72-1.65$ \\
$\quad$ Interday $(n=3)$ & $0.77-1.34$ & 87.64 \\
Limit of detection (ng/spot) & 8.05 & 265.57 \\
Limit of quantitation (ng/spot) & 24.41 & Robust \\
Robustness & Robust & Suitable for 24hr \\
Solvent suitability & Suitable for $24 \mathrm{hr}$ & \\
\hline
\end{tabular}

TABLE 5: Assay result of marketed formulation.

\begin{tabular}{|c|c|c|c|c|c|c|}
\hline Formulation & Drug & $\begin{array}{c}\text { Amount taken } \\
\text { (ng/spot) }\end{array}$ & $\begin{array}{l}\text { Amount found } \\
\text { (ng/spot) }(n=3)\end{array}$ & Labeled claim (mg) & $\begin{array}{l}\text { Amount found } \\
\text { per tablet (mg) }\end{array}$ & $\%$ Label claim \pm SD \\
\hline \multirow{2}{*}{$\begin{array}{l}\text { MYOSONE PLUS } \\
\text { (tablet) }\end{array}$} & EPE & 400 & 395.17 & 50 & 49.39 & $98.79 \pm 1.26$ \\
\hline & PCM & 2600 & 2544.47 & 325 & 318.06 & $97.86 \pm 0.84$ \\
\hline
\end{tabular}

3.2.3. Repeatability. The CV values for EPE and PCM were found to be 0.69 and 0.35 , respectively. The $\mathrm{CV}$ values were found to be $<1 \%$, which indicates that the proposed methods are repeatable.

3.2.4. Precision. The $\mathrm{CV}$ values were found to be $<2 \%$, which indicates that the proposed method is precise.

3.2.5. Limit of Detection (LOD) and Limit of Quantification (LOQ). LOD values for EPE and PCM were found to be $8.05 \mathrm{ng} / \mathrm{spot}$ and $87.64 \mathrm{ng} / \mathrm{spot}$, respectively. LOQ values for EPE and PCM were found to be $24.41 \mathrm{ng} / \mathrm{spot}$ and $265.57 \mathrm{ng} / \mathrm{spot}$, respectively. These data show that nanogram quantity of both drugs can be accurately determined (Table 4).

3.2.6. Specificity. Excipients (Starch) used in the specificity studies did not interfere with the estimation of either of the drugs by the proposed methods. Hence, the methods were found to be specific for estimation of EPE and PCM.

3.2.7. Robustness. Peak area and retention time variation were found to be $<1 \%$. Also, no significant change in peak area was observed during $24 \mathrm{hr}$. No decomposition was observed in either the first or second direction of the 2-dimensional analysis for both drugs on the HPTLC plate. Hence, the method was found to be robust for estimation of EPE and PCM.

3.2.8. Assay of the Tablet Dosage Form (EPE $50 \mathrm{mg}$ and PCM $325 \mathrm{mg}$ per Tablet). The proposed validated method was successfully applied to determine EPE and PCM in their tablet dosage form (MYOSONE PLUS). The results obtained for EPE and PCM was comparable with the corresponding labelled amounts (Table 5).

\section{Conclusion}

Thus, the objective of project work was development and comparison of analytical method of EPE and PCM in their combined dosage form. The developed and validated HPTLC method for EPE and PCM was found to be simple, specific, and cost effective and can be routinely applied for analysis of EPE and PCM in their combined dosage form. We can say that HPTLC method is more sensitive giving precise results (interday, intraday) for both drugs, and also HPTLC method is more sensitive in terms of LOD and LOQ. It also requires least solvents for analysis. The proposed method has the advantages of simplicity and convenience for the separation and quantitation of EPE and PCM in combination and can be used for the assay of their dosage form. Also, the low solvent consumption and short analytical run time lead to environmentally friendly chromatographic procedures. The additives usually present in the pharmaceutical formulations of the assayed analytes did not interfere with determination of EPE and PCM. The method can be used for the routine simultaneous analysis of EPE and PCM in pharmaceutical preparations.

\section{Disclosure}

The usage of this trade mark symbol or company name is for proving the genuinity of the work and not for any another purpose. The authors of the paper, do not have any financial relation with the commercial identity mentioned in the paper.

\section{Conflict of Interests}

The authors have no conflict of interests or no financial gains in mentioning the company names or trade marks.

\section{Acknowledgments}

The authors are thankful to Macleods Pharmaceuticals Ltd. (Mumbai, India) and Elysium Pharmaceutical Ltd. (Vadodara, India) for providing gratis sample with the great 
pleasure. The authors are also thankful to Principal and Staff of Indukaka Ipcowala College of Pharmacy (New Vallabh Vidyanagar, India) and Director of SICART (New Vallabh Vidyanagar, India) for providing the necessary facilities for research work.

\section{References}

[1] Japanese Pharmacopoeia, Government of Japan, The Ministry of Health, Labour and Welfare, 16th edition.

[2] The Merck index, An Encyclopedia of Chemicals, Drugs and Biological, Merck Research Laboratories, 13th edition, 2006.

[3] A. Beltrame, S. Grangiè, and L. Guerra, "Clinical experience with eperisone in the treatment of acute low back pain," Minerva Medica, vol. 99, no. 4, pp. 347-352, 2008.

[4] K. D. Tripathi, Essentials of Medical Pharmacology, vol. 1, Jaypee Brothers, 5th edition, 2008.

[5] British Pharmacopoeia, vol. 2, Stationery Office on Behalf of the Medicines and Healthcare Products Regulatory Agency (MHRA), London, UK, 2011.

[6] United States Pharmacopoeia and National Formulary, The United States Pharmacopoeia Convention, 24th Asian edition.

[7] Indian Pharmacopoeia, vol. 3, Government of India, Ministry of Health \& Family Welfare, the Controller \& Publication, Delhi, India, 2010.

[8] P. U. Patel, S. K. Patel, and U. J. Patel, "Spectrophotometric method for simultaneous estimation of eperisone $\mathrm{HCl}$ and diclofenac sodium in synthetic mixture," International Research Journal of Pharmacy, vol. 3, no. 9, pp. 203-206, 2012.

[9] Y. Zhang, L. Ding, X. Wei, S. Zhang, and J. Sheng, "Rapid and sensitive liquid chromatography-electrospray ionization-mass spectrometry method for the determination of eperisone in human plasma: method and clinical applications," Journal of Chromatographic Science, vol. 42, no. 5, pp. 254-258, 2004.

[10] M. S. Kondawar, R. R. Shah, J. J. Waghmare, N. D. Shah, and M. K. Malusare, "UV spectrophotometric estimation of paracetamol and lornoxicam in bulk drug and tablet dosage form using multiwavelength method," International Journal of PharmTech Research, vol. 3, no. 3, pp. 1603-1608, 2011.

[11] R. Sawant, L. Bhangale, R. Joshi, and P. Lanke, "Validated spectrophotometric methods for simultaneous estimation of Paracetamol, Domperidone and Tramadol $\mathrm{HCl}$ in pure and tablet dosage form," Journal of Chemical Metrology, vol. 4, no. 1, pp. 21-27, 2010.

[12] K. Kalra, S. Naik, G. Jarmal, and N. Mishra, "Spectrophotometric method for simultaneous estimation of paracetamol and domperidone in tablet formulation," Asian Journal of Research in Chemistry, vol. 2, no. 2, pp. 112-114, 2009.

[13] C. Narajji, H. R. Patel, M. D. Karvekar, and A. R. S. Babu, "Simultaneous estimation of aceclofenac, paracetamol and tizanidine in their combined dosage forms by spectrophotometric and RP- HPLC method," Journal of Analytical and Bioanalytical Techniques, vol. 2, article 123, 2011.

[14] S. Mahaparale, R. S. Telekone, R. P. Raut, S. S. Damle, and P. V. Kasture, "Simultaneous spectrophotometric determination of drotaverine hydrochloride and paracetamol in tablet," Indian Journal of Pharmaceutical Sciences, vol. 72, no. 1, pp. 133-136, 2010.

[15] R. B. Prasanna and M. S. Reddy, "RP-HPLC method for simultaneous estimation of paracetamol and ibuprofen in tablets,"
Asian Journal of Research in Chemistry, vol. 2, no. 1, pp. 70-72, 2009.

[16] L. Monser and F. Darghouth, "Simultaneous LC determination of paracetamol and related compounds in pharmaceutical formulations using a carbon-based column," Journal of Pharmaceutical and Biomedical Analysis, vol. 27, no. 6, pp. 851-860, 2002.

[17] N. P. Dudhane, M. J. Umekar, and R. T. Lohiya, "Validated RPHPLC method for estimation of metoclopramide hydrochloride and paracetamol in solid dosage form," Journal of Pharmaceutical Research, vol. 3, no. 12, pp. 3064-3066, 2010.

[18] A. Yadav, R. Singh, S. Mathur, P. Saini, and G. Singh, "A simple and sensitive HPTLC method for simultaneous analysis of domperidone and paracetamol in tablet dosage forms," Journal of Planar Chromatography, vol. 22, no. 6, pp. 421-424, 2009.

[19] P. B. Deshpanday, V. S. Gandhi, and S. Y. Bhangale, "HPTLC method for simultaneous estimation of etoricoxib and paracetamol in combined tablet dosage," Journal of Pharmaceutical and Biomedical Analysis, vol. 3, pp. 1-5, 2010.

[20] ICH Harmonized Tripartite Guidelines, Validation of Analytical Procedures: Text and Methodology, Q2 (R1), Geneva, Switzerland, 2005. 

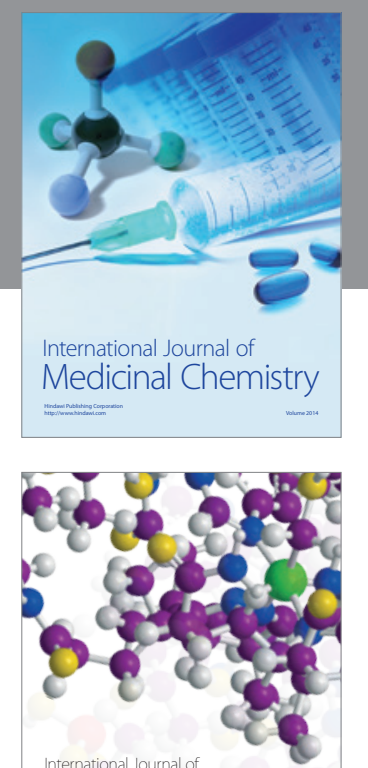

\section{Carbohydrate} Chemistry

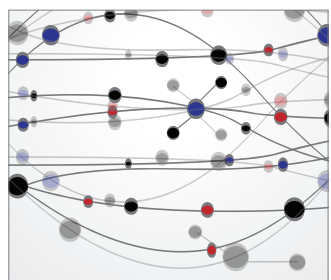

The Scientific World Journal
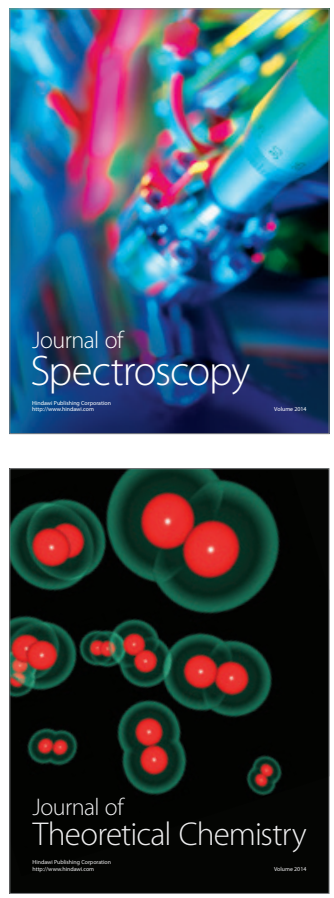
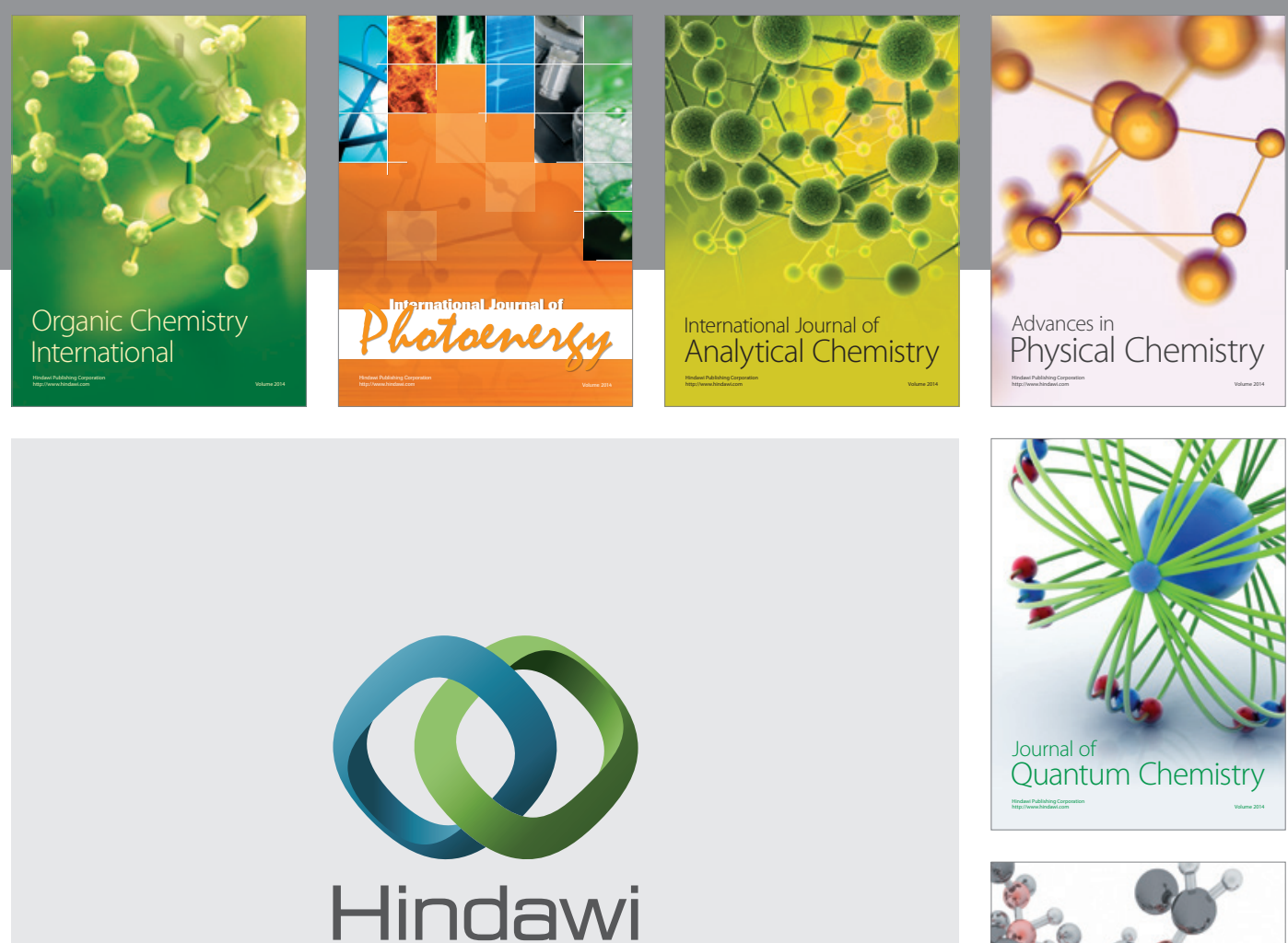

Submit your manuscripts at

http://www.hindawi.com

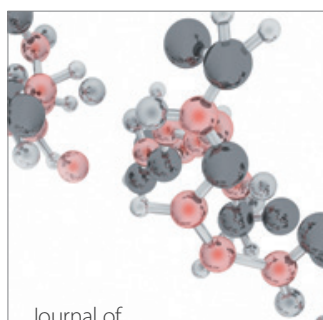

Analytical Methods

in Chemistry

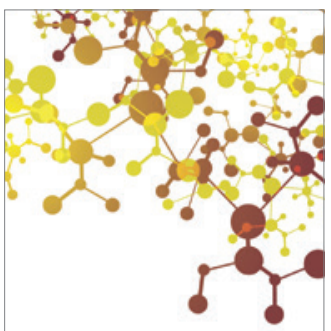

Journal of

Applied Chemistry

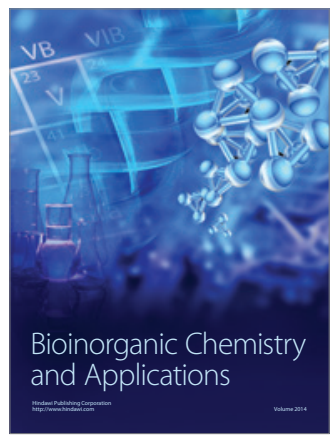

Inorganic Chemistry
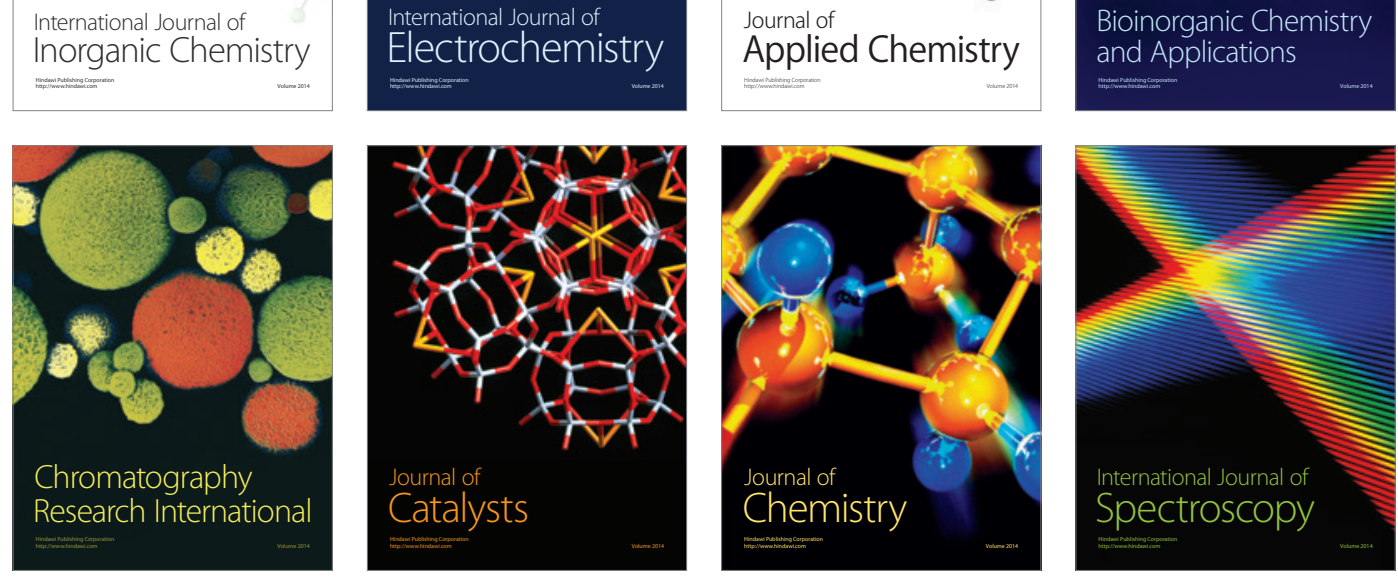